УДК 338.246.2

DOI 10.25205/978-5-4437-1268-0-41-45

\title{
И.Е. Пожилов
}

Институт Дальнего Востока РАН, Москва, Россия

\section{ФУ БОЦУЙ: 20 ЛЕТ НЕ С КПК, НЕ С ГОМИНЬДАНОМ}

Статья посвящена уникальной фигуре в китайском политикуме новейшего времени - коммунисту и члену националистической партии Фу Боцую, вошедшему в историю страны бескомпромиссным апологетом и созидателем альтернативного деревенского сообщества, вобравшего в свои основы лучшие и наиболее справедливые принципы устроения сельской общины, отличные от деревни советизированного типа и уходящего в прошлое архаичного, день ото дня ветшающего поселения на территориях господства Нанкинского правительства. В материале на основе оригинальных источников кратко анализируется жизненная стезя и деятельность зачинателя «новой деревни» в Китае, ее базовые ценности и необычные обстоятельства возникновения, независимого существования и развития в условиях непримиримого противостояния Компартии и Гоминьдана.

Ключевые слова: Фу Боцуй; «новая деревня»; КПК; Гоминьдан.

\section{E. Pozhilov}

Institute of Far Eastern Studies of Russian Academy of Science, Moscow, Russian Federation

\section{FU BOCUI: 20 YEARS NOT WITH THE CPC, NOT WITH GUOMINDANG}

The paper is devoted to a unique figure in the Chinese politicum of modern times - a communist and member of the nationalist party Fu Bocui, who went down in the history of the country as an uncompromising apologist and creator of an alternative village community, which incorporated the best and fairest principles of organizing a rural colony, different from the village of the sovietized type and leaving into the past of an archaic, day by day decaying settlement in the territories of the rule of the Nanjing government. Based on original sources, the paper briefly analyzes the life path and activities of the founder of the "new village" in China, its basic values and unusual circumstances of the emergence, independent existence and development in the conditions of irreconcilable confrontation between the Communist Party and the Guomindang.

Keywords: Fu Bocui; “new village”; the CPC; Guomindang

«Господин из Фуцзяни», как называл Фу Боцуя (1895-1993) Мао Цзэдун, принадлежал к богатому и влиятельнейшему тамошнему клану, имел блестящее образование (окончил университет Васэда в Токио по специальности «юриспруденция»; тесно общался с Сунь Ятсеном

(c) И.Е. Пожилов, 2021 
и состоял в его революционной организации; сотрудничал с крупным мыслителем-социалистом Японии начала XX в. Мусякодзи Санэацу; изучал учение марксизма и анархизм; был не чужд толстовству и другим социально-политическим теориям), пользовался искренним почитанием не только среди земляков, но и в массах за пределами родного края, будучи партийным руководителем всего-навсего уездного звена. Мятущийся, сомневающийся и порой противоречивый в идейных пристрастиях, «человек-легенда революции», как нарекли его потомки, тем не менее всегда оставался последовательным сторонником народоправства и демократии, гуманизма и справедливости, свободы личности и общества [Яо Диншэн, 1995. С. 5-6].

Пропагандируя среди крестьянства свои идеалы и в подтверждение высоких слов раздав крестьянам собственные земли, Фу Боцуй выступил непримиримым оппонентом «большевистского коммунизма», насаждаемого сталинской кликой в КПК, в свою очередь обвинявшей «крестьянского вождя» с его упованиями на «справедливый, бесклассовый, гуманный и экономически взаимовыгодный деревенский уклад», к которому он призывал коллег-партийцев, в «беспринципной демагогии». Более того, «выскочку-гуманиста» не раз подвергали суровой критике и грозили самыми суровыми мерами воздействия [Сунь Сянъян, 2009. С. 44-45].

С 1929 г. из-за острых разногласий с партийным руководством Фу Боцуй прекращает всякие контакты с КПК и вскоре официально исключается из партии ${ }^{1}$. Но движение «бунтаря» и его последователей по «пути не с КПК и не с Гоминьданом», несмотря на непрестанные выпады коммунистов против «предателя революции», продолжалось ровно 20 последующих лет, вплоть до провозглашения КНР в 1949 г.

Нельзя сказать чтобы о Фу Боцуе много писали и пишут в современной китайской исторической литературе (в отечественной историографии работ, посвященных его личности и деяниям, нет вообще). Однако те немногочисленные публикации в Китае, основанные на имеющих гриф «Для служебного пользования» документах, отличаются в целом и частностях сравнительно объективным и довольно широким подходом к исследуемой теме, характеризуются выверенностью и скрупулезностью в деталях, отличаются неортодоксальностью выводов и суждений, прежде немыслимых в такого рода изданиях. К ним в первую очередь отнесем монографию Чэнь Сайвэня [Чэнь Сайвэнь, 1995] и ряд статей авторитетных авторов из ведущих журналов континентального Китая [Сунь Сянъян, 2009; Яо Диншэн, 1995; Хуан Даосюань, 2013; Юй Линьлин, 2009; и др.]. Невзирая на общий рационально-позитивный фон, в посвященной Фу Боцую литературе, к сожалению, встречаются опусы, словно перекочевавшие в современность из времен оголтелой борьбы с «ревизионизмом» и «буржуазными пережитками», мажущими черной краской любое проявление инакомыслия [Цзян Боин, 2018]. И вместе с тем, китайским авторам, по определению приверженным марксистской догматике и методологии, явно недостает требуемой непредвзятости и взвешенности заключений, что обусловливает необходимость дальнейшего, очищенного от идеологических наслоений исследования предмета в русле последовательного историзма.

Фу Боцуй, что достойно большого сожаления, не оставил мемуаров, и это добавляет немало трудностей в анализ его удивительной биографии и исполненной созидания деятельности. И все же в распоряжении исследователей имеется, на наш взгляд, достаточно информативных материалов, дабы воссоздать его правдивый портрет и комплекс идейных убеждений.

Прежде всего обращают на себя внимание научные штудии Фу Боцуя как в Японии, так и Пекинском университете (где ему также довелось учиться и активно участвовать в «движении 4 мая»), которые отличал целенаправленный поиск концепций, способных помочь вопло-

${ }^{1}$ В это время с целью заставить инертное до всего крестьянство участвовать в «аграрной революции» коммунисты проводили в деревне иррационально жестокую политику под подобающим лозунгом «Жги и убивай!». 
тить в жизнь его мечту построить в деревне «царство свободы». Мощным толчком к этому послужила его поездка в префектуру Яманаси, где под эгидой Мусякодзи Санэацу была создана т.н. новая деревня, принципами существования которой являлись: «единение» (отрицание классовой дифференциации и классовой борьбы), «равенство», «независимость» (от государства и внешнего мира), «свобода», «гармоничное единство духовного и материального начал», норма «от каждого по способностям, каждому по труду». «Новая деревня» в Яманаси стала для Фу Боцуя воплощенным в жизнь его идеалом. Воодушевленный обретенной «ценностью высшей пробы», молодой подвижник возвращается в Китай с единственной целью - чего бы то ни стоило, реализовать на родине японский проект с учетом самобытности Поднебесной [Чэнь Сайвэнь, 1995. С. 41-42].

Его колоссальные усилия воодушевить идеей «новой деревни» товарищей по партии и руководство провинциальной парторганизации, но, главное, командование 4-го корпуса Красной Армии во главе с Мао Цзэдуном и Чжу Дэ (корпус временно дислоцировался в Западной Фуцзяни и его Фронтовой комитет представлял собой высшую инстанцию КПК по месту пребывания), как уже говорилось, натолкнулись на глухую стену непонимания. Мао с симпатией относился к фуцзяньцу и ставил его много выше других; кроме того, сам в свое время «переболел» планами построения «новой деревни» ${ }^{2}$. Но дальше дискуссий их беседы так и не пошли. В конечном итоге корпусной комиссар по-дружески рекомендовал Фу Боцую присоединиться к войскам и уйти в Цзянси, дабы не раздражать амбициозных лидеров из местных уроженцев.

Мао Цзэдун оказался прав: вскоре после ухода корпуса фуцзяньская партийная верхушка организовала вооруженную вылазку в Гуцзяо, родные места Фу Боцуя, где располагались его клановые земли и деревни семьи. Находившийся в труднодоступной горной котловине, район Гуцзяо сам по себе являлся почти неприступной крепостью, и на защиту своих домов встали как один все члены клана. Потерпев неудачу и познав непоколебимую прочность кровнородственных связей цзунцзу 宗族 ${ }^{3}$, коммунисты впредь даже не пытались предпринимать подобных карательных походов ${ }^{4}$. Со своей стороны, и чванливым гоминьдановским властям было не с руки что-то менять в сложившейся ситуации; напротив, их вполне устраивала «самостийность» Гуцзяо, персонифицированная «отступником-коммунистом» и членом Гоминьдана (с 1926 г.), способным поддерживать общественный порядок в районе и не покушаться на их полномочия и прерогативы («налоги, правда, не платит...») [Хуан Даосюань, 2013. С. 81].

Весьма примечательно, что Фу Боцуй, - а этот факт обнаружишь не в каждой публикации, - не питал вражды ни к коммунистам, изгнавшим его из партии и прямо покушавшимся на его жизнь, ни к верным сторонникам основателя Гоминьдана. На стене его рабочей комнаты в Гуцзяо мирно соседствовали и портрет Сунь Ятсена, и красное знамя с серпом и молотом. Объяснял такую «несуразицу» он просто и ясно: «Я за КПК без классовой розни и насилия»; «Я за первозданный Гоминьдан Отца нации» [Чэнь Сайвэнь, 1995. С. 92-93].

После разрыва с КПК и при попустительстве гоминьдановской администрации Фу Боцуй пришел к выводу, что «новую деревню» следует создавать не на голом месте, как в Японии с помощью приезжих волонтеров, но в родном гнезде, окруженном неприступными горами и непро-

${ }^{2}$ Идея «новой деревни» имела немало сторонников среди прогрессивной китайской интеллигенции. Достаточно сказать, что ею, будучи еще среди «левых» гоминьдановцев, увлекался Чан Кайши и пропагандировал преимущества «новой сельской жизни».

3 宗族 - деревенская община в Китае, основанная на кровном родстве, по сути не знала серьезных и, тем более, антагонистических противоречий (сводились на нет неразрывными семейными узами, равнодоступными общественными землями, взаимовыручкой, заповедями моральной экономики и пр.).

${ }^{4}$ Узнав о походе, Мао Цзэдун строго-настрого наказал своим подчиненным: «Пусть все идет своим чередом, только надо жить в мире и согласии» [Юй Линьлин, 2009. С. 25]. 
ходимыми водными преградами, которые всегда защитят от посторонних глаз и непрошенных гостей. Правда, в таком случае получалась бы не «деревенька», но целая конгломерация поселений, поскольку в его вотчину входили 41 деревня и пахотные земли площадью 450 кв. км. [Юй Линьлин, 2009. С.22]. Фу Боцуя не пугали трудности, и он с энтузиазмом принялся за дело.

На общем собрании представителей деревень глава клана выступил с программой действий и тезисно начертал, что он предлагает землякам. В частности, Фу Боцуй выступил за «справедливый передел земли между крестьянами, за «свободу и спокойствие каждого», «поставил вне закона классовую борьбу и попытки ее разжигания»; заявил о «приоритете интересов и чаяний простого крестьянина», объявил введение на всей территории «новой деревни» принципа «непартийности» (запрет на деятельность политических партий любого толка) и равенство всех граждан; предложил ввести всеобщее избирательное право для мужчин и женщин, достигших 18 лет; высшим органом власти объявил Совет самоуправления как «средоточие демократии и публичную трибуну свободного волеизъявления масс». Наконец, Фу Боцуй поставил перед собранием самый жгучий вопрос о форме землевладения, констатировав, что «наилучшим вариантом его решения может быть только коллективная собственность на землю». Кроме мелких помещиков за программу «молодого вождя», как уважительно стали называть Фу земляки, высказались все присутствовавшие [Хуан Даосюань, 2013. С. 83; Чэнь Сайвэнь, 1995. С. 101-102].

Практическими преобразованиями в деревнях ведал Комитет строительства во главе с самим Фу Боцуем, важнейшие решения которого предварительно обсуждались на общедеревенских сходах, а затем передавались на утверждение в Совет самоуправления [Юй Линьлин, 2009. С. 24].

Для финансирования реформ Комитет восстановил давно не работавшие мануфактуры, производившие предметы первой необходимости и орудия труда, была запущена бумажная фабрика, построена дорога для вывоза на продажу товаров и зерна в соседние уезды и рыночные города; организовано Кредитное товарищество для субсидирования всех нуждающихся; построены лечебницы, дом для престарелых; отремонтированы школы, в которых приступили к учебе и дети, и неграмотные взрослые; стала выходить в свет еженедельная новостная газета; проведены линии телефонной связи; и др. [Сунь Сянъян, 2009. С. 40-41].

Благодаря свободному труду масс и энергии Фу Боцуя деревни в Гуцзяо быстро обрели новый облик, появилось больше зажиточных хозяев и, напротив, сократилось число бедняков, еще больше стимулировали эффективный труд и рост доходов крестьянства «новой деревни» отныне светлые перспективы и ожидания благостного грядущего. О достижениях в обновленном районе стали писать в местной и даже центральной печати, на площадку небывалого эксперимента зачастили делегации, которые воочию убеждались в том, что «в ”новой деревне” жизнь труженика на много лучше, сытнее и отраднее, чем в советских опорных базах или на территориях под управлением правительственных чинов» [Яо Диншэн, 1995. С. 212-213].

Вторжение японских агрессоров нарушило размеренное бытие жителей Гуцзяо и расстроило планы преобразований. С другой стороны, в политику «новой деревни» Фу Боцуй внес существенные коррективы. Чтобы противостоять общему врагу требовались совместные усилия и координированные действия. С этой целью с коммунистами было достигнуто «Соглашение о взаимодействии и разграничении боевых районов», а от гоминьдановских властей «молодому вождю» пришлось принять официальное назначение на должность командующего уездными отрядами самообороны. «Триединство сил» сыграло большую роль в партизанской войне с врагом, способствовало сплочению населения уезда, содействовало упорству сопротивления захватчикам [Чэнь Сайвэнь, 1995. С. 148-150].

В развернувшейся следом за победой над японским милитаризмом гражданской войне между КПК и Гоминьданом Фу Боцуй, напротив, придерживался «строжайшего невмешательства» в их вооруженную борьбу и не позволял себе ни единого шага, способного бросить тень на его нейтрализм. Однако к исходу схватки за власть Фу Боцую все-таки пришлось сделать 
судьбоносный выбор и в мае 1949 г. повернуть оружие против «полностью скомпрометировавших себя националистов». Восставший Гуцзяо с радостью приветствовал приход в Фуцзянь передовых частей Народно-освободительной армии и принял участие в боестолкновениях с остатками войск Гоминьдана [Чэнь Сайвэнь, 1995. С. 178-179].

В Новом Китае по протекции Мао Цзэдуна его давний оппонент был назначен председателем провинциального народного суда, энергично занимался общественной деятельностью, неоднократно избирался депутатом Народного политического консультативного совета Китая (НПКСК); не без участия Председателя пережил страшные годы «культурной революции». А в 1986 г., на 91-м году жизни, убедившись, что страна твердо идет по пути реформ и открытости, вновь стал членом Коммунистической партии, тем самым поставив точку в своей поразительной политической карьере.

Китайские авторы в своих публикациях нетривиальные перипетии в судьбе Фу Боцуя и, в частности, его детище «новую деревню» нередко называют «третьим путем», имея в виду коренные отличия его политики и практики от «коммунистической революции», исповедуемой большинством в КПК, равно как и «разительные контрасты с партийно-государственным курсом правящего Гоминьдана». Некоторая доля исторической истины в этом, несомненно, присутствует и имеет право на существование. Однако в чистоте использование термина «третий путь», по нашему мнению, не совсем или совсем не корректно. Фу Боцуй всегда оставался верен марксизму без его крайностей - классовой борьбы и насилия, никогда не изменял учению Сунь Ятсена с его базовым постулатом «каждому пахарю свое поле», но без пустого мечтательства и фантазерства. Его кредо неизменно заключалось в том, чтобы, заимствуя и применяя только рациональные зерна этих, а также иных идеологий, заниматься строительством общества гуманизма, свободы и справедливости. И, конечно же, «не с КПК и не с Гоминьданом».

\section{Список литературы}

Сунь Сянъян. Гэмин цижэнь Фу Боцуй дэ фэнъюй жэньшэн [孙向阳。革命奇人傅柏翠的 风雨人生]. Жизнь и судьба человека-легенды революции Фу Боцуя // Данши цзунлань [党史纵 览]. 2009. № 2. С. 42-46. (на кит. яз.)

Хуан Даосюань. Цижэнь Фу Боцуй [黄道炫。奇人傅柏翠]. Легендарный человек Фу Боцуй // Луньянь данши цзыляо юй яньцзю [龙岩党史资料与研究]. 2013. № 32. С. 77-85. (на кит. яз.)

Цзян Боин. Цун гэмин дао фаньпань: 1927-1931 нянь Фу Боцуй дэ жэньшэн гуйцзи [蒋 伯英。从革命到反叛: 1927-1931年傅柏翠的人生轨迹]. От революции к предательству: извилистый жизненный путь Фу Боцуя в 1927-1931 гг. // Суцюй яньцзю [苏区研究]. 2018. № 5. С. 13-22. (на кит. яз.)

Чэнь Сайвэнь. Чуаньци жэньу - Фу Боцуй [陈赛文。传奇人物 - 傅柏翠]. Легендарная личность - Фу Боцуй. Пекин: Чжунго жэньши чубаньшэ, 1995. 256 с. (на кит. яз.)

Юй Линьлин. Гэмин цижэнь Фу Боцуй дэ фэнъюй жэньшэн [俞琳玲。革命奇人傅柏翠的 风雨人生]. Жизнь и судьба легенды революции Фу Боцуя // Данши цзунлань [党史纵览]. 2009. № 2. С. 19-26. (на кит. яз.)

Яо Диншэн. Цюйчжэ цянь баньшэн - Фу Боцуй чжуань [姚鼎生。曲折前半生 - 傅柏翠 传]. Биография Фу Боцуя: извилистая первая половина жизни. Пекин: Чжунгун данши чубаньшэ, 1995. 285 с. (на кит. яз.) 